\title{
The Killer Father and the Final Mother: Womb-Envy in The Cell
}

\author{
SHWETA SHARMA, St Mary's University College
}

\section{ABSTRACT}

This paper introduces and examines the 'Killer' Father and the 'Final' Mother in Tarsem Singh's The Cell (2001). They are descendants of Carol J. Clover's 'Killer' and 'Final Girl' respectively. The Killer Father is a bad father figure who tortures or even kills his family. The Final Mother is a 'muscle mother', who kills the Killer Father in order to save her child from his fringes. This study uses the psychoanalytical concept of 'womb-envy' as a critical tool to illustrate the unconscious motives of the Killer Father. The employment of womb-envy shows that the Killer Father's behaviour displays unconscious envy of the female reproductive organs, and the capacity to give birth and nurture. In the end, this paper argues that the presence of the Killer Father and the Final Mother in the contemporary horror cinema is indicative of the dilemmas that preoccupy modern parenthood and the agency of the nuclear family.

\section{KEYWORDS}

Womb envy; Final Mother; Killer Father; The Cell; Psychoanalysis; Horror cinema.

\section{Introduction}

'Freud is the father of psychoanalysis. It has no mother.'

(Germaine Greer)

Science fiction and horror are two film genres that most explicitly represent what is repressed in society. This paper will draw on representations in films of the bad father, referred to here as the 'Killer' Father (Clover, 1992, pp.26-30), the sort of character who gets drunk, tortures, hurts or even kills his wife and children. This paper deals with the figure of the Killer Father not through the exploration of social factors like economic suppression, the career oriented woman etc. that lead a man to torture and kill his own family; but explore the unconscious motives that might be the cause of such behaviour. This paper will then put forward a feminist reading of the Killer Father through the employment of the psychoanalytical concept of 'wombenvy' (Kittay, 1983, pp.94-128); and elaborate on the possible unconscious motives of such a figure. The Killer Father, his actions, behaviour, motives and existence will be studied through a brief analysis of The Cell (Tarsem Singh, 2001). This paper will also show that the figure of the Killer Father is central to the reading of contemporary horror, and functions as an important comment on post-nuclear family. In the end, this paper will also identify and explore the strong mother figure, referred to here as the 'Final' Mother (Clover, 1992, pp.35-41), the sort of mother who kills the Killer Father and puts an end to his monstrous deeds. 
The reader should however be aware of the concepts - the 'Killer', 'Final Girl' and 'womb-envy' that this paper will use. This paper draws on Carol J. Clover's ideas of the 'Killer' and the 'Final Girl' as associated with the slasher genre. This paper, however, does not agree with Clover's reading of the two character types within Victorian flagellation literature, her conclusion that they are women/men in drag, and figuratively the slasher film shows 'male-on-male sex' (Clover, 1992, p.52). This is not to deny that the Killer Father and the Final Mother are descendants of Clover's Killer and Final Girl; or The Cell is a post-modern slasher film. However, this study holds at its heart the feminist perspective (unlike Clover's orthodox influences of Thomas Laqueur and Victorian flagellation literature) which sees the slasher film's avenging victim-hero, as progressive and feminist. Similarly, the Killer, who will now be explored as the Killer Father, will also be acknowledged as progressive. This paper will use these two character types and give a viewpoint on feminist discourses like male domination of the family, suppression and degradation of women, the contempt expressed for feminine biology, male desire for the child, among others.

The reader must also be aware that it is beyond the scope of this paper to locate the psychoanalytical concept of 'womb-envy' and trace its academic origins - whether it was first formulated by Karen Horney or Margaret Mead or Melanie Klein or Evelyn Keller Fox or Eva Feder Kittay or whether it was suppressed by Sigmund Freud. Neither will this paper justify, verify or bring to question the usefulness of wombenvy as a corollary to penis envy, and the picture of female sexuality as presented by Freud.

Not widely debated within mainstream psychoanalysis, but acknowledged, directly or indirectly in most feminist literature, womb-envy is the envy man shows, implicitly or explicitly of woman's reproductive functions, especially her power to give birth and mother. This envy can be traced in man's desire to achieve immortality through work, a boy child, proliferation of his own race; his desire to become a woman; his desire to compete with woman's reproductive organs through the development of technology; his desire to confirm the woman to monogamy, the Law of the father's name, the issue of illegitimate child - all for his ultimate desire of patriarchy's 'right' child; by treating women merely as agents of reproduction, sexual fulfilment and by confirming them to domestic labour - unpaid or underpaid; through misogynist and abusive behaviour in name of keeping the Law and creating the perfect family (the Killer Father's category) (al-Hibri, 1983, pp.81-93; Kittay, 1983, pp.94-128).

The importance of womb-envy as a concept can be traced by looking at recent films like Children of Men (Alfonso Cuarón, 2006). E. Ann Kaplan shows that in post-1975 period, the study of the mother involves an exploration of reproductive discourses and anxiety that surrounds the womb (Kaplan, 1992, pp.180-219). A few main reasons for this anxiety are technological development, the women's movement and the subsequent entry of women into workforce. With more women choosing a career over having babies, the question of who will reproduce in the future has taken male imagination by storm. Films with cyborgs (The Terminator, James Cameron, 1984), men having babies (Junior, Ivan Reitman, 1994), and a talking foetus (Look Who's Talking, Amy Heckerling, 1989) signify the upheaval caused by this social anxiety. The other manifestations of womb-envy may not specifically have to do with technology but with the revelation that the patriarchal unconscious envies a woman's 
capacity to reproduce and mother. The concept is also useful to define and explain feminine traits that are repressed in the male through patriarchal upbringing. This paper will give womb-envy within representation, a clear focus; as a concern that needs more than just feminist generalisations.

\title{
The Cell/The Womb: the beginning
}

\author{
'That is a place of evil.' \\ 'In what world do you live in?'
}

The key to the mystery of The Cell lies within the title itself. Carl Rudolph Stargher (Vincent D'Onofrio) captures unsuspecting beautiful blonde women for the perverse needs of his mentally disturbed mind, and sexually repressed self. (From here onwards adult Carl, who is a serial killer will be referred as 'Carl'. The young boy of Carl's subconscious will be referred as 'boy Carl'). He does this with the help of his angel like, rare albino dog, Valentine (indeed Carl's only true love). He apprehends women and takes them to an underground space, which is where the cell is located.

The cell is a huge, high ceiling glass cubicle - a place where the victim is tortured. The torturing procedure is automated and is marked by Carl's absence until after the victim's death. The victim gains consciousness only to find herself trapped in something beyond her understanding. The entire procedure, the victim's cries for mercy for being left alone and tortured, are recorded by cameras that surround the cell; Carl makes a new video for each of his victims. The cell provides the victim with a place to sit down, some food, a basin and a toilet. And in course of 40 hours, the victim is tormented with loneliness, misery, anxiety, and the water that overhead showers sprinkle once in a while, at first only terrifying the victim, but by the end drowning the victim. Carl comes to release the water and remove the dead body from the cell. The dead woman's body is cleaned with bleach and showers; she is then transformed into Carl's perverse doll figure. He makes a peculiar metal collar for each of his victims, and then leaves them at a water source for the police to discover.

The cell symbolises the surrogate womb of Carl's serial killer mind. His mental and sexual abilities/disabilities are a stand in for every man, their need and desire, but their inability to fully participate in giving birth to a new life. Carl's disturbed mind does what a civilised man's mind living a repressed society cannot, it tries to give birth. He abducts women from the cultured human world, for the proliferation of his own twisted world. This he does by trapping them in his surrogate womb, just like the mother's womb holds a baby. The cell like the womb feeds the child, and nourishes it with its water, till the time it is ready to be born. The water in the mother's womb nurtures the child till it is ready to be born; however, in Carl's surrogate womb, the water does not nourish the victim but suffocates it to death. The death of the civilised woman ensures her eventual birth in Carl's repressed world; so that the water of the cell is not life-taking, but birth giving. Once the victim is dead (or rather alive) and ready to come out, Carl releases the water, and brings the woman to his world. What follows next is after birth cleansing and feeding the new born with milk like bleach. He stitches, fabricates and makes them into a doll, the woman of his world. He earmarks them by putting an identical collar around their neck, classifying them as his 
property, and leaves them at the nearest water source to be found and discovered as his creation, his gift to society.

What is even more interesting is that Carl always and only captures women. His actions display misogyny; he tames, tortures and makes his victims into man's idealised vision of a woman, a doll. But most importantly, his actions are envious. The cell which functions as a surrogate womb is an indication of Carl's subconscious desire to give birth like a woman, and become a woman; he suffers and displays a frank inferiority complex by trying to create a life all by himself. The fact that he kidnaps only women and brings them to his perverse world is an indication of his belief that woman because of her biological capacity to give birth, feed, nurture and mother, is a superior being, and the only one fit to live in his world.

In the same line of thought, it is also worth observing instances where the film evokes the use of water. Edward Baines (Colton James) is afraid to go sailing, the water that fills up the cell, the water that is released from the cell, Carl in his bathtub, his memories of his baptism, his father's threat to drown him, the bird he drowns as a child etc. Water as a source evokes the unconscious feeling of maternal plenitude, maternal loss, the fear to return to womb, the desire for the womb, all which works simultaneously in the film. In fact, that is where the difference between Edward and Carl lies. If Edward's more reasonable and less disturbed mind is afraid to go sailing, afraid to go back to a state of maternal plenitude; Carl living in his perverse kingdom desires to stay inside the water, it desires for union with the woman, incorporate the woman and even become the woman.

Another reason why he makes women into dolls is because his sexually frigid and repressed self seeks sexual fulfilment only through this process; by suspending himself on the ceiling, reaching a state of orgasm through the pain involved in such a tedious procedure. The recorded videos of torture and cries for sympathy playing on high volume on a side function on a perverse level, as the woman's cries of joy in the union. They also function on another level; as an indicator of the voyeurism and envious feelings involved in Carl's activities, and then brings our mind to recent developments like that of being able to take pictures of the foetus in development, which Kaplan earmarks when discussing post-1975 anxiety expressed in relation to the womb (Kaplan, 1992, pp.180-219).

\section{The Killer Father: the story}

'Me got boy; Boy me got. You cannot kill me!'

Unlike any other film that implicitly points out to the subconscious as a place that triggers actions and behaviour; The Cell actually introduces a procedure through which it is possible to engage with the subconscious, unravel the neurosis a person suffers from, and through a human presence in the subconscious, actually solve dilemmas that influence conscious and rational behaviour.

Catherine Deane's (Jennifer Lopez) second journey into Carl's mind explains what he has gone through as a child. A part of the second dream sequence has a long distance shot of a house, where boy Carl nervous and intimidated is wiping dishes. Catherine's 
interruption causes a plate to break, which frightens boy Carl, and he hides Catherine in the storeroom. Through Catherine's perspective, we see Carl's father scold boy Carl for breaking the plate. He throws the dishes around, yells and acts abusively.

At one instance, we see Carl's father sitting in his underwear, watching television. On his side is a woman, wearing a dressing gown, with her breasts showing and legs apart, whom Carl's father calls a 'whore'. While abusing boy Carl, he reminds him that the woman is not his mother, and mentions that his mother left them. He then pushes him against the woman's parted legs saying, 'This is the place of evil.' We witness another episode, when his father enters boy Carl's room, and hits him with his belt because he is playing with dolls (the kind of doll that Carl holds in his hand while looking at Julia Hickson (Tara Subkoff) as a potential doll). His father calls him a 'faggot,' 'mama's boy' because of boy Carl's feminine habit of playing with dolls. He then hurts boy Carl with a hot iron, and gives him 'something to cry about like a woman.'

Carl's father is an abusive father. He makes a young boy do domestic work, and acts cruelly when he makes a mistake. He threatens boy Carl, shouts, breaks his ribs and fractures his jaw, without the slightest blink of his eye. He treats boy Carl like a second rate being. It does not come as a surprise that Carl's mother has left the family (as Carl's father informs boy Carl), or has Carl's father taken the boy child away from his mother (as one of the three abstract figures inform Peter Novak (Vince Vaughn)) or has Carl's father killed Carl's mother? Neither does the environment of boy Carl's house, with dad in underwear, and a shabbily dressed woman, seem like the best of places for a boy to grow-up.

Boy Carl likes to play with dolls, and his father rebukes him for indulging in such feminine acts, including crying. The doll, a toy usually given to girls, is associated with 'feminine instincts' like mothering, nurturing, dressing up, and keeping the house tidy. As per traditional gender roles, boy toys like building blocks, steam engines, action heroes are associated with 'male instincts' like constructing, technological curiosity, patriotism, strength and bravery. Carl's father wants his son to grow up and become a man, a valued being, and not become the devalued woman, whom he immensely hates, who is subjected to her biology, never ending trauma and tears. Hence, he tortures him for displaying any feminine traits that may taint boy Carl's, and most importantly his own manhood.

The repression of boy Carl's feminine desires, the formation of the narcissistic wound, and the eventual womb-envy Carl displays as an adult, are comprehensively explained by Kittay's thesis of how every young boy, like his mother, wants to have babies and nurture them. However, through patriarchal upbringing and entry into the Symbolic, he envies the womb, and eventually either devalues the source of envy like Carl's father, or devalues himself like Carl. Everything goes to say, if Carl's feminine traits were cherished and accepted, then he would have grownup to be someone who would respect women, associate with the joys of giving birth, and equally participate in the nurturance of his own children. Kittay writes:

The knowledge of the young boy that his procreative contribution is of equal significance and that he, as well as his sister, will have the opportunity to recreate and create anew infancy and childhood in an intimate relation with a 
child, may dissipate what envious desires he might feel vis-à-vis the biological distinction. If the gratification from 'the good object' is what will dissipate envy, while each defense constructed out of envy ultimately fuels that envy, then only empathetic involvement with pregnancy and childbirth, and most important, involvement with early childcare, will successfully provide for men the gratification needed to dissipate womb envy

(Kittay, 1983, pp.94-128)

The view of Carl's subconscious activities shows that Carl's father and not Carl is the real monster; that Carl has learnt his repressive behaviour from his dominating father. His misogynistic activities, and the subconscious womb-envy they display, are a partaking of his father, of what his father has made him. From his father he has learnt how to act contemptuously towards women, and make them available for his repressed birth-giving and sexual desires. Carl has learnt about sexuality his father's way; his father's dominating, abusive sexuality that regards women as evil is passed on to the next generation, and converted by Carl into his repressive, perverse and neurotic sexuality.

Another very important feature that is consistent in the representation of Carl's subconscious is that he perceives himself as a 6-year-old young and innocent boy, who still has to come with terms with the mysteries of life. His adult-self and his father are someone boy Carl wants to escape. At a subconscious level, Carl and Carl's father are displaced versions of one another. Carl (a result of distorted upbringing), i.e., his father is the tormentor, the king who rules adult Carl's twisted mind, and who makes him kill.

\section{The Final Mother: the end}

'He found me. He always finds me.'

'My world my rules!'

Carl is boy Carl's father figure at a subconscious level, and by the end of the film, Catherine becomes his surrogate mother. Carl is the Killer Father, who tortures his family and kills young women (who show signs of their budding sexuality). Catherine, who is brave enough to travel into his world; who gets captured in the cell of Carl's subconscious (and escapes by herself); who is possessed by Carl with a metal collar around her neck, and gets lost in his world (and is rescued by Peter); who becomes boy Carl's surrogate mother and wants to save him; is the Final Mother, the only one able to kill the Killer Father.

From the beginning of the film, Catherine is portrayed as a caring individual, the surrogate and archaic mother of all things. She is a child psychologist by profession, which means her womanhood, her love for children and her profession are two sides of the same coin. Catherine, the mother figure is the only one Edward chooses to make contact with, hence joint session therapy is a failure. This simply means that in the narrative of The Cell, the task of bringing up and understanding a child is only the mother's, and there is no need of the father figure. The scene when Catherine is at her home wearing her underwear, caressing and feeding the cat is evocative of the feminist hero Ellen Ripley (Sigourney Weaver) in Alien (Ridley Scott, 1979), who is 
not just a strong woman but can be seen as a mother figure as well. The pictures of Kali Mata and Maa Durga on the walls of Catherine's home are reminiscent of the warrior woman who destroys evil. Catherine even dreams of rescuing Edward from his plight; all she really wants to do is save distressed children. Catherine agrees to do a risky job of going into Carl's mind, and does the same twice, even after the first bad experience, because she cares for Julia. Once inside Carl's mind she tries her best to reach boy Carl in an attempt to find Julia, and eventually even fixes his neurosis.

One of her arguments from the beginning of the film is to reverse the feed of the procedure and let Edward or Carl come into her mind, rather than vice versa. In her opinion, her mind, the world of the mother is a better environment for a child to flourish and prosper in, rather than staying back in his own creepy dwelling, which we eventually learnt is the realm of the Killer Father. Once Peter learns how to find Julia, she reverses the feed and lets Carl enter his mind, with the aim to do things her way and to give Carl's subconscious a resolution. In doing so, she almost jeopardises her career (as Henry West (Dylan Baker) reminds her) by accessing unauthorised area, reversing the feed without permission, and risks her life as well.

The utopian world of Catherine's subconscious is heavenly white with snowfall, pink blossom trees, white peacocks and lotus flowers floating in a crystal clear pond. Dressed in white and red, as the Virgin Mary, she holds a conversation with boy Carl, who asks if he can stay there in her world. Catherine explains that is not how it works, and that there is nothing that she can do about it. Then suddenly, boy Carl becomes the adult Carl, and says there is something she can do about it. He tells her how as a little boy he had found an injured bird and brought him home. He was afraid that his father would do something horrible to the bird, so instead he saved the injured bird by holding it under the sink, which he believes was better for the bird. Catherine says that she cannot and will not do anything like this. Carl becomes boy Carl again, and informs him that it does not matter since his father has found him.

Catherine's heaven becomes dark and gloomy, and the Killer Father makes his reptile like presence felt, first on boy Carl's body as insects, and then as the snake in the pond. The Killer Father emerges from the snake in the pond. Catherine changes her garb from the Virgin Mary to that of a female warrior, does things her way, and hits the Killer Father with several arrows, punches him and finally stabs him a number of times with her sword. In course of killing him, the face of the Killer Father changes to that of Carl, who tells her to kill them. The Killer Father declares in his monstrous laugh that whatever is happening is not real, that he has boy [Carl] and that she cannot kill him. Catherine turns and looks at boy Carl near the pond, who is also stabbed with the Killer Father. She becomes Virgin Mary again, holds boy Carl, who tells her to save him. She tells him that he can stay there with her, and slowly takes him to the pond, and drowns him.

Catherine's personification as the Virgin Mary confirms her motherly status in the film. Boy Carl's request to stay back in Catherine's world justifies his desire to return to a state of maternal bliss, and his longing for union with the mother. Her refusal and explanation that she cannot let boy Carl live in her world is the acknowledgment of how life works. It is the acceptance of the truth that all of us live in the man's world, the world of the father, and the mother's world is only a fantasy. It also means that boy Carl cannot live in the mother's world because it is only through the father that 
he can enter the Symbolic, and become a man, whereas a life in the mother's world signifies neurosis, the kind that boy Carl might (does) suffer.

His explanation of finding an injured bird and being afraid of what his father might do to it, is indicative of his fear of what his father might do (has done) to him. Because of his helplessness like the bird, boy Carl has to withstand what life has in store for him, especially his father. His act of holding the bird under the sink, of saving it, of giving it freedom by letting it return to the womb is symbolic of his need to be saved, and baptised (which his subconscious frequently evokes) not into the hell of his father's world but the heaven of an angel like mother.

Catherine's subsequent mention of her inability to save Carl, and to initiate him into her world, is the fear of the mother to make her rules and do things her way. It is indicative of a mother's lack of confidence in taking the child away from the father, of her doubt in her ability to bring up the child all by herself, of providing him everything in the father's absence, and to create a world beyond the clutches of patriarchy and the name of the father. At another level, where boy Carl's life in the mother's world symbolises death and neurosis; Catherine as a mother cannot kill her own child. This because a mother through the process of giving birth and bringing a new life into the world, locates the joys of living life despite the hurdles and sufferings which are a part of life.

The sudden appearance of the Killer Father in Catherine's world shows that it is not easy for a woman/mother to renounce the patriarchal world she lives in. This is particularly true, when there is a child, especially a boy child involved in the dispute. For man, a boy child is a source to achieve immortality, since he insures a life long existence of his seed and his name - another manifestation of womb-envy. The Killer Father's reptile like presence in Catherine's heavenly world is a sign that (the name of) the father will always loom in the life of the mother and the child, no matter what she does, and no matter where they go, (it) he will always find them.

Catherine transforms from the Virgin to a warrior woman in order to deal with the Killer Father. She becomes an incarnation of Maa Durga (the inaccessible mother), the Hindu goddess of feminine and creative energy. Catherine's act of killing the Killer Father (Carl and his father) is reminiscent of Maa Durga's slaughter of the twoface demon Mahishasur, who could change between human and buffalo (mahisha means buffalo). This because Mahishasur was born out of a union between the king of demons, Rambha and a water buffalo. Mahishasur had the boon that he could not be defeated by any man or god (see this in light of the Final Girl being the only one able to kill the Killer). Among several manifestations of the Killer Father is the one where his scalp and neck are white, with two horns on his head.

The Killer Father's short lived but significant transformation into Carl asking Catherine to kill them, shows that they both are displaced versions of each other, and the monster that lives in Carl is a result of distorted upbringing. The Killer Father's declaration that Catherine's act of killing him is not real is indicative at two levels. First, that Catherine, the surrogate mother or boy Carl's real mother can only kill him at a subconscious level. Second, his remark explains that in real life the mother can never kill an abusive father because both the child and she are dependent on father for their living. His comment is on the patriarchal belief that a brave, independent, 
financially autonomous mother figure, who can get rid of the abusive father is only a feminist fantasy.

His declaration that he has got the boy (Carl) and that she cannot kill him is indicative of his belief that Catherine's Final Mother is only a day dream, and that in the end of the day, he has got (literally) boy Carl, the boy child that patriarchy desires. Catherine breaks into tears not for killing the father but for killing the child along with the father. Boy Carl asks her to save him, like he had saved the bird. Catherine's approval of keeping boy Carl in her world is suggestive that a mother can claim her child to herself (that too only symbolically since boy Carl is dead), only after eliminating the father. Catherine lets boy Carl stay in her world. She takes his bleeding body to the pond and initiates him to the place of his deepest desire, the mother's womb.

\section{The Killer Father and the Final Mother: conclusion}

This paper recognises two character types, the Killer Father and the Final Mother in the contemporary horror film. They are an extension of Clover's Killer and Final Girl in the slasher genre. These characters are studied in The Cell through the employment of the psychoanalytical concept of womb-envy. Womb-envy is the unconscious envious feelings that man shows towards the female capacity to give birth and nurture.

A brief analysis of The Cell shows that Carl tries to give birth by abducting and killing women through the automated procedure of the cell, which drowns them. The cell acts as Carl's surrogate womb and symbolises his desire to give birth. While exploring the Killer Father, the paper shows how Carl as a child has been abused by his dominating father. Carl has learnt his sexually repressive behaviour from his father. The repression of Carl's feminine traits has made him into a serial killer, who envies the womb. At a subconscious level, Carl and his father are displaced versions of one another, and hence they are revealed as the Killer Father, the sort of father who tortures and tries to kill his own family. Catherine is revealed as boy Carl's surrogate mother at a subconscious level. She brings boy Carl to her world and tries to sort his subconscious dilemmas. When the Killer Father makes his appearance in her world, she emerges as the Final Mother and kills him.

The Cell comments on contemporary cinema's ambivalence on the agency of the nuclear family which has existed since Rousseau. The Cell shows how the father, traditionally the key figure of the nuclear family is now actually threatening its very existence. The child, the symbol which brings the man and woman together in a nuclear family, and which symbolises the happiness in their union is now in distress and in need of rescue from the fringes of the father. In such a situation the mother's social position has changed from passive to active, to the one who rescues the child from the father. The use of womb-envy as a critical tool is particularly useful to understand the forces which are leading to the deterioration of the nuclear family, and the subsequent increase in woman-headed families.

Catherine's Final Mother figure offers the audiences a feminist fantasy of an independent and strong woman, whose profession is child-care. Catherine's profession does not make her a bad mother, the kind of mother who does not give 
birth and participate in the upbringing of the child because of her career. Her profession as a child psychologist makes her a good mother and a strong, progressive career woman as well. The fact that she is willing to put her life and career at a risk (by reversing the feed) for the resolution of a serial killer's subconscious, symbolises not only her capacity and desire to nurture but also to move ahead in career. At the level of combining a demanding career and motherhood, and being successful in both, Catherine's image is only a compromise.

The only male figure that the audiences can identify with is the humble FBI agent Peter. Peter, who was formerly an advocate by profession, became an FBI agent to find a child molester, who had escaped the clutches of law. When Catherine dressed as the Virgin Mary baptises boy Carl into the mother's womb, Peter finds and releases Julia from Carl's surrogate womb. Both Catherine and Peter as surrogate parents offer the images of strong, sensitive, nurturing and caring individuals, which is the film's message about contemporary parenthood. But to the extent that rescuing, caring, mothering and being brave are the skills both father and mother makes use at workplace as well, is more than problematic.

The employment of womb-envy to analyse The Cell is only one example. The concept of womb-envy can be used to study a wide range of mainstream representations that not only centre on the father but the working mother, the single mother and even the Final Mother. The recognition of the Killer Father and Final Mother in contemporary horror can be most useful in understanding the distressed child, who has to live with an abusive father, and a mother, who still has to come to terms with the choices in life.

\section{References}

al-Hibri, A. (1983) Reproduction, Mothering and the Origins of Patriarchy. In: Trebilcot, J., ed. Mothering: Essays in Feminist Theory, New Jersey: Rowman and Allanheld, 1983, pp.81-93

Clover, C.J. (1992) Men, Women and Chainsaws: Gender in the Modern Horror Film. New Jersey: Princeton University Press

Conlon, J. (1996) The Place of Passion. In: Grant, B.K., ed. The Dread of Difference Gender and the Horror Film. Austin: University of Texas Press, 1996, pp.401-411

Creed, B. (1993) Dark Desires. In: Cohan, S. and Hark, I.R., eds. Screening the Male: Exploring Masculinities in Hollywood Cinema, London: Routledge, 1993, pp.118-133

Creed, B. (1993) The Monstrous-Feminine: Film, Feminism and Psychoanalysis. London: Routledge

Doherty, T. (1996) Genre, Gender and the Aliens Trilogy. In: Grant, B.K., ed. The Dread of Difference: Gender and the Horror Film, Austin: University of Texas Press, 1996, pp.181-199 
Erens, P.B. (1996) The Stepfather: Father as Monster. In: Grant, B.K., ed. The Dread of Difference: Gender and the Horror Film, Austin: University of Texas Press, 1996, pp.352-363

Greer, G, (online). Available from:

http://www.quotationspage.com/search.php3?homesearch=greer\&startsearch=Search [accessed 29.11.07)

Horney, K. (1967) Feminine Psychology. New York: W.W. Norton

Jeffords, S. (1993) Can Masculinity be Terminated? In: Cohan, S. and Hark, I.R., eds. Screening the Male: Exploring Masculinities in Hollywood Cinema. London: Routledge, 1993, pp.245-262

Kaplan, E.A. (1992) Motherhood and Representation: The Mother in Popular Culture and Melodrama. London: Routledge

Kittay, E.F. (1983) Womb Envy: An Explanatory Concept. In: Trebilcot, J., ed. Mothering: Essays in Feminist Theory. New Jersey: Rowman and Allanheld, 1983, pp.94-128

Lehman, P. (1993) 'Don't Blame this on a Girl. In: Cohan, S., and Hark, I.R., eds. Screening the Male: Exploring Masculinities in Hollywood Cinema. London: Routledge, 1983 pp.103-117

Lindsey, S.S (1996) Horror, Femininity and Carrie's Monstrous Puberty. In: Grant, B.K., ed. The Dread of Difference: Gender and the Horror Film. Austin: University of Texas Press, 1996, pp.279-295

Robbins, H.W. (1993) More Human than I am Alone. In: Cohan, S. and Hark, I.R., eds. Screening the Male: Exploring Masculinities in Hollywood Cinema. London: Routledge, 1993, pp.134-147

Sobchack, V. (1996) Bringing It all Back Home. In: Grant, B.K., ed. The Dread of Difference: Gender and the Horror Film. Austin: University of Texas Press, 1996, pp.143-163

Williams, T. (1996) Trying to Survive on the Darker Side. In: Grant, B.K., ed. The Dread of Difference: Gender and the Horror Film. Austin: University of Texas Press, 1996, pp.164-180

Wright, E. [ed.] (1992) Feminism and Psychoanalysis: A Critical Dictionary. Oxford: Blackwell Publishers 